\title{
Motivation matters: predicting students' career decidedness and intention to drop out after the first year in higher education
}

\author{
Carina Bargmann $^{1} \cdot$ Lisa Thiele $^{1} \cdot$ Simone Kauffeld $^{1}$
}

Accepted: 15 March 2021/ Published online: 29 March 2021

(C) The Author(s) 2021

\begin{abstract}
Higher education institutions are striving to lower student dropout rates to increase the number of academically qualified persons in the labour market and decrease misguided investment. Researchers generally acknowledge that students who are firmly decided on their studies tend to drop out of their studies less frequently. Building on the extended expectancy-value model via the cost component, this longitudinal study investigates changes in and the impact of students' motivation on career decidedness and intention to drop out. We analysed data from 351 first-year university students aiming to become teachers across three measurement points, finding that the task effort of students and, to a lesser degree, their interest value was related to career decidedness and, indirectly, to the intention to drop out after the first year in higher education. Moreover, the results revealed that these students' ability beliefs increased and interest value decreased from the beginning to the end of the first year at higher education. Accordingly, we discuss the theoretical and practical implications taken from these findings.
\end{abstract}

Keywords Career decidedness · Dropout intention - Expectancy value theory · Ability beliefs . Students $\cdot$ Longitudinal study

Student dropouts in higher education are a major problem in Europe (European Commission, 2015). The average dropout rate in 23 OECD countries for which data are available is $33 \%$ for undergraduate students (Organisation for Economic Co-operation and Development [OECD], 2019). In Germany, the reported student dropout rate is slightly lower but still too high (20$30 \%$; Heublein et al., 2017; Scherfer \& Weber, 2014) and leads to an economic loss of around 2.2 billion euros (Leffers, 2007).

Carina Bargmann

c.bargmann@tu-bs.de

1 Department of Industrial/Organizational and Social Psychology, Institute of Psychology, TU

Braunschweig, Spielmannstr. 19, 38106, Braunschweig, Germany 
The longer students stay in unsuitable study programmes, the higher the costs will be, affecting politics, society and students (Arce et al., 2015; Bennett, 2003; Klöpping et al., 2017). Thus, the increase in the average length of bachelor's degree-level study before dropping out in recent years is concerning (Heublein et al., 2017).

Most students leaving university have already considered dropping out within the first year (Heublein et al., 2017), which - beginning with the choice of study - is a critical point in career decision-making (Guo et al., 2015; Tett et al., 2017). At the beginning of study, students' career decidedness is assumed to be high. Afterwards, the process that potentially leads to dropping out may involve two steps: students first free themselves from their study choice and decrease their career decidedness, then build the intention to drop out of their study programme. During the first year, students face complex personal and organisational requirements and are less familiar with the organisational structures of the new learning environment (Brinkworth et al., 2009; Trautwein \& Bosse, 2017). Because prospective students must make their study choice with no or little experience regarding the considered study courses (Blüthmann et al., 2011; Sarcletti \& Müller, 2011), they mostly report unrealistic expectations regarding their initiated studies and feel overwhelmed by the transition into university (Brinkworth et al., 2009; Crisp et al., 2009; van der Meer et al., 2018). Research has shown this mismatch of expectation and reality to lead to a loss of commitment in prospective teachers (Perryman \& Calvert, 2019). Unsurprisingly, students free themselves from their study choice and decrease their career decidedness upon recognising that their studies do not match their expectations.

A vital factor affecting the choice of studies, persistence in studies, and performance is individuals' motivation towards their studies and even their intended profession (Brahm et al., 2017; Heublein et al., 2017; Mikkonen et al., 2013; Richardson et al., 2012; Trautwein \& Stolz, 2015; Wigfield \& Eccles, 2000). According to the expectancy-value model (EVM; Wigfield \& Eccles, 2000), students' motivation comprises two components: expectancy and value. Additionally, current research emphasises the role of costs as a third component of motivation (Barron \& Hulleman, 2015; Jiang et al., 2018). One aspect of cost is the task effort. For example, a student who assesses the task effort as too high might be less motivated, even with high expectancy and value for a task (Barron \& Hulleman, 2015). However, to the best of our knowledge, no research has yet investigated the additional aspect of cost together with the expectancy and value of first-year students and how they relate to career decidedness and dropout intention. Hence, we focus especially on the study-related ability beliefs (expectancy), interest value (value) and task effort (cost) students experience in the first year to further extend research addressing how school-related ability beliefs and interest in school subjects influence students' choice of study and academic success (Guo et al., 2015; Le et al., 2014). When students choose an area of study, their ability beliefs and interest value are expected to be high (Wigfield \& Eccles, 2000). However, research findings on motivational development in higher education are inconsistent because of varying study designs and conceptualisations of motivational development (Coertjens et al., 2017). Scherrer and Preckel's (2019) metaanalysis revealed a decrease in intrinsic motivation during the school career. Other studies on students have indicated decreasing intrinsic motivation, especially in the first year at university (Brahm et al., 2017; Busse, 2013). A decrease in motivation is associated with declining career decidedness and eventually dropping out (Heublein et al., 2017; Perez et al., 2014; Schnettler et al., 2020).

Thus, this study sought to examine how students' ability beliefs and interest value change within the first year and how both ability beliefs and interest value together with task effort might influence career decidedness and dropout intention after 1 year. 
This study contributes to previous research in several ways. First, we expanded on the current research by considering all three motivational components (ability beliefs, interest value and task effort) of the extended EVM. Second, we applied the extended EVM for the first time to first-year students to predict their career decidedness after the first year and their intention to drop out afterwards. Thus, we expanded our understanding of the determinants in the complex process that leads to students dropping out. Within the first year, students recognise whether their chosen studies meet their ability beliefs and interest value and can estimate their study-related task effort. Students who are disappointed by their study condition will presumably reduce their career decidedness and take the first step towards dropping out. Accordingly, early identification of students who are engaging in this process would be desirable to decrease both the students' and institutions' investment of time and resources. Hence, our study contributes to extending the understanding of student dropouts. Finally, we investigated changes in ability beliefs and interest value between the time when students selected their course of study and when they completed their first year.

Our findings form the basis for practical recommendations for universities, counsellors and students.

\section{Student dropouts and career decidedness}

The early semesters are critical for later dropouts and academic success (e.g. Brahm et al., 2017; Jenert et al., 2015; Heublein et al., 2017). About 58\% of students who end up dropping out think about dropping out during the first year. Students report two main reasons for considering dropping out in their first year: lack of motivation and valuable career alternatives (Heublein et al., 2017).

In this context, lower career decidedness may be an early step in the process of dropping out. The degree of career decidedness reflects students' level of confidence about their chosen course of study and degree of commitment to their studies (Gordon, 1998; Li et al., 2019; Robbins et al., 2006). Students who realise that they are losing their study motivation often report lower career decidedness at the same time (Betz \& Voyten, 1997). Research has also shown that pre-service teachers who experience low commitment to their career decision are more likely to drop out of their study programme (Klassen \& Chiu, 2011; Roberts, 2012). In contrast, pre-service teachers who reported certainty about engaging in the teaching profession and satisfaction with their career choice during their studies tended to persist until graduation (Eren \& Rakıcıoğlu-Söylemez, 2020; Hobson et al., 2009). Correspondingly, a low degree of career decidedness can be a warning signal for dropping out of studies later. A high degree of career decidedness after the first year should be accompanied by a low intention to drop out afterwards. Moving from right to left on the model (Fig. 1), we assume the following:

Hypothesis 1: Career decidedness after the first year is inversely related to dropout intention in the following semester.

\section{Ability beliefs, interest value and task effort}

Research on transition and study success emphasises the relevance of students' motivation (Girelli et al., 2018; Mikkonen et al., 2013; Noyens et al., 2019; Richardson et al., 2012; Trautwein \& Stolz, 2015). Eccles's expectancy-value model of achievement-related choices (EVM), which has had a 


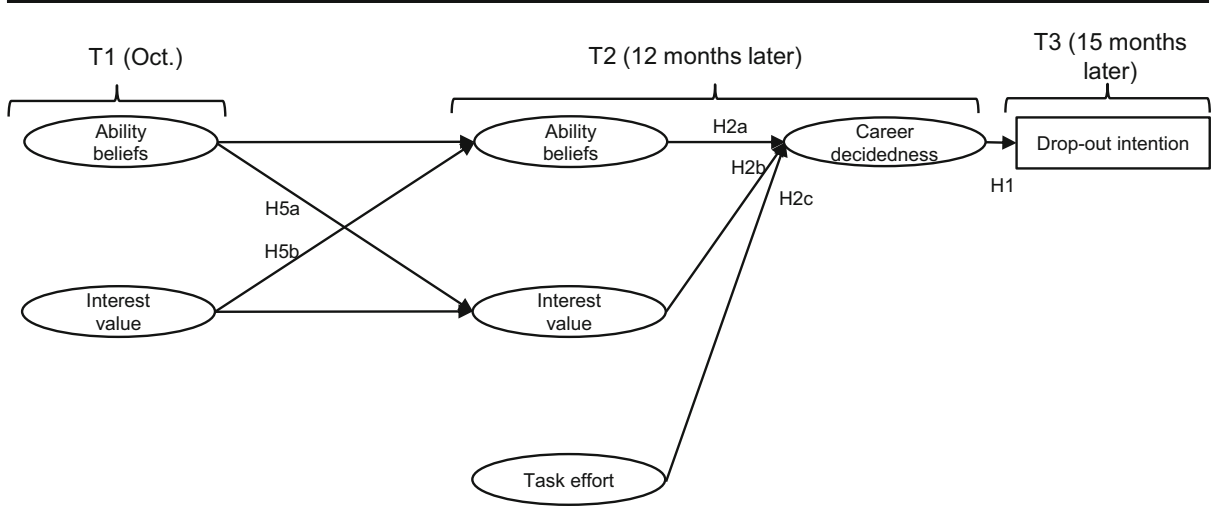

Fig. 1 Research model

wide influence on educational research (Eccles et al., 1983; Wigfield \& Eccles, 2000; Eccles \& Wigfield, 2020), focuses on two motivation components. The expectancy component (i.e. ability belief) corresponds to beliefs about one's own competence (Eccles \& Wigfield, 2002). Ability beliefs are close to the social cognitive theory's construct of self-efficacy (Bandura, 1991). Various studies have shown that students' self-efficacy is a major predictor of academic performance and persistence (Lent et al., 1994; Schaeper, 2020; Wright et al., 2013).

The value component (i.e. interest value) corresponds to the value that someone attaches to a task and contains the subfactor students' interest. The interest value refers to the enjoyment felt when performing a task and is synonymous with the intrinsic motivation within self-determination theory (SDT), which has also been shown to be predictive for students' retention and academic development (Deci et al., 1996; Duchatelet \& Donche, 2019; Schnettler et al., 2020; Eccles \& Wigfield, 2020). Since both theories and empirical studies emphasise the importance of ability beliefs and interest value, we have focused on these two components in this study.

Furthermore, our study includes task effort, defined as the cost an individual will need to put into the completion of a task (Eccles et al., 1983). Recent research considering cost as an added component to expectancy and value has asserted that the multiple dimensions of expectancies, value and cost act separately (Barron \& Hulleman, 2015; Gaspard et al., 2017; Watt et al., 2019).

Several links exist from ability beliefs, interest value and task effort to career decidedness and intention to drop out. Students who have a strong belief in their study-related abilities may be better able to meet study requirements and perform successfully on study-related tasks (Restubog et al., 2010). One meta-analysis of pre-service and in-service teachers found that their self-efficacy beliefs were positively related to their commitment to the teaching profession (Chesnut \& Burley, 2015), translating to a high degree of career decidedness. In contrast, students without a strong belief in their own study-related abilities might report a low degree of career decidedness (Restubog et al., 2010). Interest value might be similar (Mikkonen et al., 2013; Schnettler et al., 2020): Students' low level of interest in their studies might be related to low career decidedness and the intention to drop out. A study investigating Chinese pre-service teachers showed that intrinsic motivation was the best predictor of satisfaction with the chosen profession (An et al., 2020).

Moreover, students in their first year at university find themselves challenged by study requirements for the first time (Briggs et al., 2012; Jenert et al., 2015; Leese, 2010; Trautwein $\&$ Bosse, 2017) but frequently have not anticipated these requirements. As a result, they 
misjudge the requirements and perceived task effort during their first year as unexpectedly high (Aymans \& Kauffeld, 2015; Brinkworth et al., 2009; Crisp et al., 2009). Thus, students who regard their effort towards their studies as overwhelming are presumably more likely to reconsider their career choice. Accordingly, they have a lower level of career decidedness.

Hypothesis 2: Students' (a) ability beliefs and (b) interest value after the first year are positively related to career decidedness.

Hypothesis 2c: Task effort after the first year is negatively related to career decidedness.

Based on the previous considerations, we assume that career decidedness mediates the relationship between the three motivational components and dropout intention. This assumption is supported by research on undergraduates in a teacher training programme and a nursing programme, which indicated that career decidedness mediates the relationship of self-efficacy to students' dropping out (Restubog et al., 2010; Roberts, 2012). However, to the best of our knowledge, whether career decidedness mediates the relationship of interest value and task effort with the intention to drop out has not yet been investigated.

Hypothesis 3: Career decidedness after the first year at university mediates the relationship between (a) ability beliefs, (b) interest value and (c) task effort and the intention to drop out in the following semester.

\section{Why ability beliefs and interest value change during the first year}

The EVM assumes that individuals' beliefs in their abilities and interest value change over time, and these changes can be caused by changes in contextual factors (Eccles et al., 1983; Watt, 2004; Wigfield \& Cambria, 2010; Wigfield \& Eccles, 2000). The transitional period from school to university represents the first time when students must make a fundamental career decision. Within university, research showed interest value to be more decisive for students' dropout intention than ability beliefs, which are among the strongest psychological predictors of performance (Perez et al., 2014; Schnettler et al., 2020). Because interest value and ability beliefs are positively related, each exerts both indirect and direct effects on performance and decisions (Wigfield \& Cambria, 2010; Wigfield \& Eccles, 2000). Therefore, prospective students presumably report a relatively high value for interest and ability beliefs in their chosen study programme. That said, first-year students typically have little experience in their chosen studies and, therefore, unrealistic expectations regarding the requirements at university (Brinkworth et al., 2009; Crisp et al., 2009; Sarcletti \& Müller, 2011). Thus, their interest values might be unstable during the transition period. Recent research has demonstrated that students' intrinsic motivation decreases over time (Brahm et al., 2017; Jacobs et al., 2002; Schnettler et al., 2020; Watt, 2004). Longitudinal studies on the development of students' intrinsic motivation and self-perceptions during school have indicated the same trend (Scherrer \& Preckel, 2019; Watt, 2004; Wigfield et al., 1991). Because first-year students encounter new requirements in their studies that they might find overwhelming (van der Meer et al., 2018), they may reduce their interest value and ability beliefs during their first year.

Hypothesis 4: During the first year, (a) students' ability beliefs and (b) their interest value will decrease.

Interest value and ability beliefs are positively related over time (Eccles et al., 1983; Eccles \& Wigfield, 2020). Therefore, we hypothesise a bidirectional relationship between ability beliefs and interest value. 
Hypothesis 5: Students' (a) ability beliefs at the beginning of their studies are related to the interest value after 1 year and (b) vice versa.

\section{Method}

\section{Sample and procedure}

The study was part of a comprehensive research project evaluating the development of prospective teachers. The participants in this complete survey of all pre-service teachers included 351 undergraduates enrolled in a teacher-training programme in Germany in two cohorts: 188 in Cohort 1, 163 in Cohort 2. The sample consisted of $74.6 \%$ women and $25.4 \%$ men. The average age was 20.43 years $(\mathrm{SD}=2.91)$. Table 1 reports participant characteristics for Cohort 1 and Cohort 2.

The participants were recruited in the first week of their studies in October (Cohort 1 in 2016, Cohort 2 in 2017) when the initial survey took place (T1). The surveys were tailored for the best possible integration into their study programme, with the second survey (T2) 12 months later at the end of the first year at university and the third survey (T3), which included only the outcome intention to drop out, 15 months after the first survey. Participation was voluntary. After providing informed consent, the participants completed the surveys.

Missing data and careless responses are great challenges in longitudinal research (Goodman \& Blum, 1996; Graham, 2009; Meade \& Craig, 2012). In our study, 872 students participated in the first survey, but 310 of these did not participate at T2. We also conducted a careless response analysis to increase the data quality of the remaining 562 cases. Following Meade and Craig's (2012) recommendations, we inserted one instructed response item ('To monitor quality, please respond with $40 \%$ for this item') and one self-report measure ('I have filled out the survey carefully') and conducted odd-even correlation and LongString analysis using the package 'careless' in R (Yentes \& Wilhelm, 2018). Based on an analysis of the special items, 126 cases were eliminated. A further 85 cases were eliminated based on odd-even correlation and LongString analysis. A sample of 351 cases resulted. Of these 351 remaining cases, 306 provided information at $\mathrm{T} 3$.

In line with Goodman and Blum (1996), we performed binary logistic regression to test for bias in our results. The participation pattern (remained vs eliminated) was regressed on gender, age, grade-point average (GPA) and intention to drop out at T1. Results showed that significantly more women and participants who reported better GPA (Table 2) remained in the study. The discussion will cover this study limitation in more detail.

Table 1 Participant characteristics

\begin{tabular}{lllll}
\hline Construct & Group & $N$ & Mean & SD \\
\hline \multirow{2}{*}{ Age } & Cohort 1 & 187 & 20.60 & 3.32 \\
& Cohort 2 & 163 & 20.25 & 2.36 \\
GPA & Cohort 1 & 175 & 2.58 & 0.51 \\
& Cohort 2 & 162 & 2.56 & 0.53 \\
First-generation students & Cohort 1 & 188 & 1.57 & 0.50 \\
\multirow{2}{*}{ Intention to drop out } & Cohort 2 & 163 & 1.71 & 0.45 \\
& Cohort 1 & 181 & 1.29 & 0.53 \\
& Cohort 2 & 156 & 1.42 & 0.64 \\
\hline
\end{tabular}




\section{Measures}

Interest value and ability belief were measured at T1 and T2. Task effort and career decidedness were measured at T2. The outcome intention to drop out was measured at T3. Table 3 offers a summary of all measurement instruments.

Ability belief and interest value were measured using the German 'Motivations for Choosing Teacher Education' (FEMOLA; Pohlmann \& Möller, 2010).

The study-related task effort was measured using a German-language version of the task effort scale (Flake et al., 2015).

Career decidedness was measured using the career decidedness scale (Nägele \& Neuenschwander, 2015).

The intention to drop out was evaluated using a one-item measure based on the transtheoretical model (Aymans \& Kauffeld, 2015; Klonek et al., 2015). The item offers five university statuses, from 1 (deciding to drop out) to 5 (deciding to persist).

\section{Analytic strategy}

We conducted structural equation modelling in Mplus8 to address our research questions (Muthén \& Muthén, 1998-2017) and used SPSS Version 24.0 for the descriptive analyses and to test hypothesis 4 using repeated measures ANOVA.

The hypothesised model was analysed using the two-step modelling approach (Kline, 2016). The first step involved running two exploratory structural equation modelling (ESEM) models to analyse the factor structure and test for measurement invariance across cohorts and measurement times. As recommended by Marsh et al. (2010), we used an oblique geomin rotation with an epsilon value of 0.5 . We conducted $\Delta \chi 2$ tests to compare the relative fit of the models in the analysis for measurement invariance (Table 4).

For the second step, which tested the structural relationships among the constructs, we used full information maximum likelihood (FIML) and the maximum likelihood estimation (MLR). Several fit indices were used to assess the adequacy of the model (Kline, 2016; Wang \& Wang, 2012): chi-square, the comparative fit index (CFI), the Tucker-Lewis index (TLI) and the root-mean-square error of approximation (RMSEA). Values for the relative chi-square $\left(\mathrm{Chi}^{2} / \mathrm{df}\right)$ below 2 represented a good fit, values under 3 indicated an acceptable fit. Values for the TLI and CFI closer to 1 represented a good-fitting model. A value of .08 or less for RMSEA represented acceptable fit (Wang \& Wang, 2012).

Table 2 Results of binary logistic regression model (remained vs eliminated)

\begin{tabular}{|c|c|c|c|c|}
\hline & \multirow[b]{2}{*}{$\mathrm{B}(\mathrm{SE})$} & \multicolumn{3}{|c|}{$95 \%$ CI for odds ratio } \\
\hline & & Lower & Odds ratio & Upper \\
\hline \multicolumn{5}{|c|}{ Remained vs eliminated } \\
\hline Intercept & $1.36(0.66)^{*}$ & & & \\
\hline Age & $-0.02(0.02)$ & 0.94 & 0.99 & 1.03 \\
\hline Gender & $-0.33(0.16)^{*}$ & 0.52 & 0.72 & 0.99 \\
\hline GPA & $-0.29(0.14)^{*}$ & 0.57 & 0.75 & 0.98 \\
\hline Intention to drop out & $-0.16(0.12)$ & 0.68 & 0.85 & 1.07 \\
\hline
\end{tabular}


Table 3 Means, standard deviations and correlation coefficients of measurement instruments

\begin{tabular}{lllllllllll}
\hline Construct & $k$ & Time & $M$ & SD & 1 & 2 & 3 & 4 & 5 & 6 \\
\hline 1. Interest value & 5 & T1 & 3.44 & 0.47 & .847 & & & & & \\
2. Interest value & 5 & T2 & 3.29 & 0.56 & $.518^{* *}$ & .887 & & & & \\
3. Ability belief & 5 & $\mathrm{~T} 1$ & 3.28 & 0.46 & $.193 * *$ & $.116^{*}$ & .761 & & & \\
4. Ability belief & 5 & $\mathrm{~T} 2$ & 3.36 & 0.48 & $.287 * *$ & $.349 * *$ & $.503 * *$ & .823 & & \\
5. Task effort & 5 & $\mathrm{~T} 2$ & 4.66 & 1.82 & $-.136^{*}$ & $-.143^{*}$ & -.064 & $-.134^{*}$ & .932 & \\
6. Career decidedness & 3 & $\mathrm{~T} 2$ & 4.79 & 1.19 & $.237^{* *}$ & $.382^{* *}$ & $.182^{* *}$ & $.330^{* *}$ & $-.238^{* *}$ & .844 \\
7. Dropout intention & 1 & $\mathrm{~T} 3$ & 1.26 & 0.68 & -.048 & $-.200^{* *}$ & -.034 & -.115 & $.208^{* *}$ & $-.339^{* *}$ \\
\hline
\end{tabular}

Note. $N=239$. Cronbach's alpha on the diagonal. $301 \leq N \leq 342$; item examples for interest value and ability belief begin with 'I have chosen the teacher training programme because ...'; participants provided responses along a continuum from 1 (does not apply at all) to 4 (totally true) for interest value and ability beliefs and along a continuum from 1 (strongly disagree) to 9 (strongly agree) for task effort and along a continuum from 1 (strongly disagree) to 6 (strongly agree) for career decidedness

$* p<.05, * * p<.01$

We also considered the autoregressive path of interest value and ability beliefs between the two measurement points in the SEM. Empirical evidence suggests that ability beliefs strongly predict later ability beliefs and initial interest strongly predicts ongoing interest (Wigfield \& Cambria, 2010). Moreover, ability beliefs and interest value are assumed to be positively interlinked, and both are negatively related to task effort. Therefore, in our SEM, we considered that the three components were correlated at one measurement time.

To test the mediation hypotheses $3 \mathrm{a}, 3 \mathrm{~b}$ and $3 \mathrm{c}$, we considered the total, direct and indirect effect within the structural equation model.

\section{Results}

\section{Descriptive results and ESEM first step}

Table 4 provides goodness of fit indexes for the ESEM. The models showed acceptable to good fit with the data for scalar measurement invariance across the cohorts. The model fit was worse in the scalar invariance model than the metric invariance model. We also identified the source of noninvariance and tested a partial invariant model, which showed good fit with the data. Thus, we assumed invariance across cohorts and measurement times.

\section{ESEM second step}

The results demonstrated that the hypothesised model based on the partial scalar measurement invariance model had a good fit with the data, $\chi^{2}(358)=505.41, p<.000, \chi^{2} / \mathrm{df}=1.41, \mathrm{CFI}=$ $.97, \mathrm{TLI}=.96, \mathrm{RMSEA}=.034 \mathrm{CI}=[.027, .041], \mathrm{SRMR}=.047$. Figure 2 displays the model. Overall, for the ESEM model, factor loadings of each latent variable were statistically significant $(p<.001)$ and above .43 , which was above the minimum acceptable criterion (.32; Tabachnick \& Fidell, 2006). The model explained $13.7 \%$ in the variance of intention to drop out and $28.9 \%$ of career decidedness variance. Ability beliefs and interest value were interlinked $\left(r_{\mathrm{T} 1}=.11, p=.003 ; \mathrm{r}_{\mathrm{T} 2}=.26, p<.000\right)$. Notably, the relationship was stronger after 
Table 4 Goodness-of-fit statistics and information criteria of group invariance and longitudinal invariance for ESEM models

\begin{tabular}{|c|c|c|c|c|c|c|}
\hline Model & RMSEA & CFI & TLI & SRMR & $\chi^{2}$ & df \\
\hline \multicolumn{7}{|l|}{ Cohorts at $\mathrm{T} 1$} \\
\hline Configural & & & & & 99.99 & 52 \\
\hline Metric & & & & & 120.13 & 68 \\
\hline Scalar & & & & & 133.40 & 76 \\
\hline \multicolumn{7}{|l|}{ Cohorts at $\mathrm{T} 2$} \\
\hline Configural & & & & & 251.06 & 174 \\
\hline Metric & & & & & 308.06 & 230 \\
\hline Scalar & & & & & 323.08 & 244 \\
\hline \multicolumn{7}{|l|}{ Across time } \\
\hline Configural & .035 & .969 & .962 & .040 & 440.86 & 309 \\
\hline Metric & .034 & .969 & .964 & .045 & 456.92 & 325 \\
\hline Scalar & .035 & .967 & .962 & .047 & 4.73 .94 & 333 \\
\hline Partial scalar & .034 & .968 & .964 & .046 & 466.06 & 332 \\
\hline
\end{tabular}

ESEM, exploratory structural equation modelling; CFI, comparative fit index; TLI, Tucker-Lewis index; SRMR, standardised root-mean-square; $d f$, degrees of freedom

the first year. Task effort had negative but not significant relationships with both ability beliefs and interest value.

We found that career decidedness was negatively related to dropout intention 3 months later $(\beta=-.27, p=.001)$, supporting hypothesis 1 .

Ability beliefs $(\beta=.23, p<.001)$ and interest value $(\beta=.37, p<.001)$ were positively linked to career decidedness. Task effort $(\beta=-.13, p=.018)$ was negatively linked to career decidedness. These values explained $28.9 \%$ of the variation in career decidedness. Thus, hypotheses $2 \mathrm{a}, 2 \mathrm{~b}$ and $2 \mathrm{c}$ were supported.

The mediation role of career decidedness was partly supported. Significant total effects emerged for interest value $(\beta=-.16, p=.019)$ and task effort $(\beta=.18, p<.001)$ but not for ability beliefs $(\beta=-.07, p=.259)$. Thus, the precondition for the mediation effect of ability beliefs was not found. The results revealed that the indirect path of interest value to dropout intention via career decidedness was significant $(\beta=-.10, p=.009)$. The direct effect was insignificant when controlled for career decidedness. Therefore, a full mediation model and hypothesis $3 \mathrm{~b}$ were supported. The indirect path of task effort to dropout intention via career

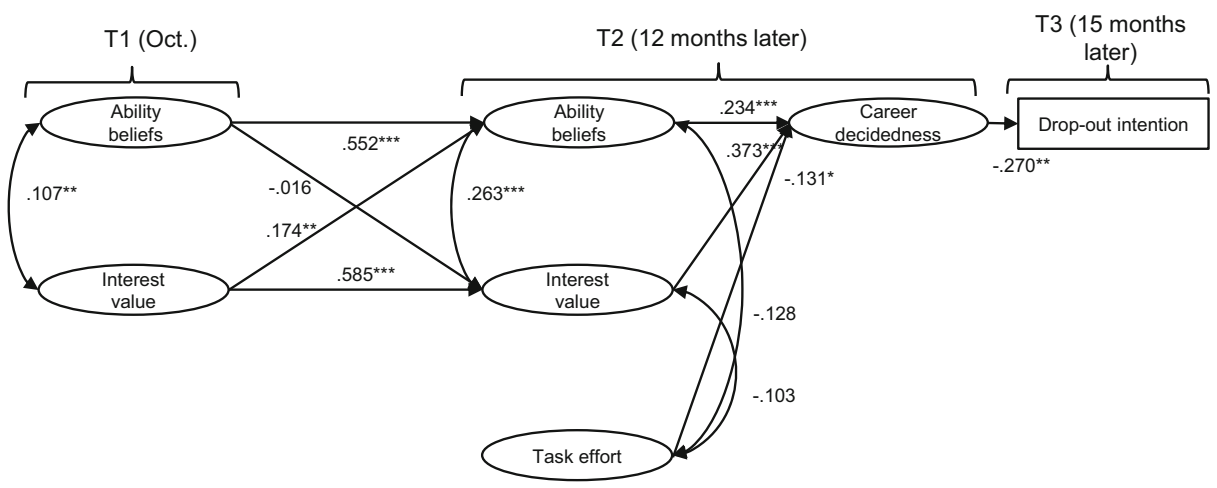

Fig. 2 Final structural mediated model with standardised regression coefficients. $N=351$, *** $p<.001$, ** $p<$ $.01, * p<.05$ 
decidedness was not significant $(\beta=.04, p=.052)$, hence, rejecting hypothesis $3 \mathrm{a}$ and $3 \mathrm{c}$. There was evidence for a direct effect of task effort on dropout intention $(\beta=.15, p=.003)$. Altogether, the variables explained $13.7 \%$ of the variance in dropout intention.

Interest value showed significant cross-sectional effects on ability beliefs $(\beta=.17, p=.003)$ but not vice versa. Therefore, hypothesis $5 \mathrm{~b}$ was supported, but $5 \mathrm{a}$ was rejected.

\section{Repeated measures ANOVA}

Ability beliefs increased, but not significantly, from T1 to T2 $(F(1)=3.89, p=.05)$. Moreover, the interest value decreased $(F(1)=24.46, p<.001)$. Thus, hypothesis 4 a was rejected, and $4 \mathrm{~b}$ was supported. The SEM also showed significant autoregressive effects for both ability beliefs $(\beta=.55, p<.001)$ and interest value $(\beta=.59, p<.001)$.

\section{Discussion}

The present study examined how students' beliefs in their abilities, their interest value and task effort were related to career decidedness after the first year in higher education and the intention to drop out 3 months later. Moreover, we examined how ability beliefs and interest value may change over the first year. Therefore, we applied the expectancy-value model to first-year students' longitudinal data.

Our findings reveal that all three motivational factors had predictive relationships with career decidedness. Interestingly, task effort showed no significant correlation with ability beliefs and interest value after the first year compared to other studies (Barron \& Hulleman, 2015; Jiang et al., 2018), perhaps because of the ESEM approach used. ESEM approaches are recommended because they better represent the data structure, which leads to lower correlations (Marsh et al., 2010). Therefore, the resulting model supported task effort as an additional predictor for career decidedness and indicated that career decidedness was more interest- and cost-directed and less ability belief-directed.

Our model yielded some evidence that ability beliefs may not affect intention to drop out, which appears to conflict with social cognitive theory (Lent et al., 1994) while in line with recent research (Barron \& Hulleman, 2015; Jiang et al., 2018; Schnettler et al., 2020), highlighting interest value and cost as more important than ability beliefs as predictors of choice and continued interest in studying a topic. Our model supported that career decidedness is the full mediator of relationship between interest value and dropout intention. This finding is in line with previous research emphasising the role of individual interest in the meaningful study of a subject (Mikkonen et al., 2013; Schnettler et al., 2020). Furthermore, our results showed a direct effect of task effort on dropout intention, which supports taking all three motivational components into account for academic outcomes, in line with recent research (Barron \& Hulleman, 2015; Jiang et al., 2018; Schnettler et al., 2020; Watt et al., 2019).

All three motivational components seem to be driving forces in students' career decidedness. Nevertheless, only interest value via career decidedness and task effort directly affect students' persistence in their chosen study programme.

Several aspects regarding the development of ability beliefs and interest value during the first year are interesting. Surprisingly, a comparison between the beginning of study and 1 year later revealed different change trends for ability beliefs and interest value. The interest value decreased, reflecting previous findings (Brahm et al., 2017; Busse, 2013; Jacobs et al., 2002; 
Scherrer \& Preckel, 2019). Unlike to previous studies on schoolchildren, no significant change emerged in ability beliefs (Jacobs et al., 2002; Scherrer \& Preckel, 2019). The discrepancy compared to our study results may be due to differences between the first year at university and formal schooling. In contrast to school classes, first-year students often lack direct feedback from their lecturers and have less obligation to display their competencies. Moreover, students are freer to manage their daily living and learning sessions.

Our model indicates that students who reported a high interest value displayed higher ability beliefs afterwards than students with lower interest values. High interest in studies may lead to engagement during the first year, potentially resulting in positive feedback and, consequently, higher ability beliefs after the first year. Interestingly, no effect of ability beliefs on interest value was found afterwards. This finding contrasts with earlier research emphasising that competence beliefs influenced interest value and that changes in ability beliefs had an impact on changes in interest values (Eccles \& Wigfield, 1995; Jacobs et al., 2002). However, this finding stem from the data collection schedule. Gore (2006) found that only ability beliefs obtained during studies predicted academic outcomes. Thus, students' assessment of their ability beliefs before the first semester might not be realistic and might have to be reassessed during the semester before able to act as a predictor of academic outcomes.

Nevertheless, our results extend the current research by taking all three motivational components (ability beliefs, interest value and task effort) into account and identifying task effort as a considerable predictor for career decidedness and intention to drop out.

\section{Implications}

\section{Theoretical}

Our study contributes to the previous research on student dropouts by applying the extended expectancy-value model to first-year students' career decidedness and dropout intention. Students' interest value tends to decrease over their first year of study. Lower interest values result in lower career decidedness, potentially a first step in the process of dropping out. Moreover, task effort seems a crucial determinant within this process, directly affecting career decidedness and intention to drop out. Thus, our study supports recent findings (Barron \& Hulleman, 2015; Gaspard et al., 2017; Watt et al., 2019) on the extension of the EVM to the expectancy-value-cost model (EVCM). Notably, students' ability beliefs seem to predict their career decidedness but not intention to drop out. Thus, our study might contribute to understanding the dropout process in that the findings might indicate that the motivational determinants (ability beliefs, interest value and task effort) affect the process of dropping out of university study in different ways. High ability beliefs and interest value seem primarily relevant for maintaining a career choice by being associated with high career decidedness, which might prevent someone from dropping out. Nevertheless, students think about dropping out of university if they perceive the current task effort to be too high. Thus, distinguishing among the ways that motivational determinants affect students' decisions to drop out could be appropriate.

\section{Practical}

Essential implications exist for educators, career counsellors and students concerned with the early career decisions of first-year students and their career decidedness. 
Our results may indicate the risk that two negative effects combine in the first year at university. First, students' interest value declines slightly during this year. Second, students become aware of the task effort and may perceive study-related task effort as high. Together, lower interest value and perceived task effort lead to lower career decidedness and higher intention to drop out 3 months later, highlighting the necessity of both in students' reflections regarding their career decisions. Moreover, universities should evaluate whether certain study conditions affect students' task effort, meeting the challenge of balancing necessary task effort with task effort that is too high. Institutions should also consider that first-year students are less familiar with the organisational structures of the new learning environment (Brinkworth et al., 2009).

Furthermore, universities could offer support services for first-year students. For example, counselling interviews could take place with students following their first year to evaluate their study motivation and career decidedness. Asking students who report lower interest value and high task effort to choose from two possible options might be appropriate. First, students should consider dropping out early and pursuing an alternative career to preclude investing time and resources in a study programme that is unsuitable for them. Second, students should ponder how to increase their interest value and face the perceived task effort to strengthen their career decidedness. Research has demonstrated that students' intrinsic motivation can increase again after the first year (Brahm et al., 2017; Lieberman \& Remedios, 2007). Therefore, the counselling should be open to any result and support students on each career path.

Furthermore, more information on the study framework could be provided to prospective students to allow them to better anticipate the workload related to their studies (cf. Aymans \& Kauffeld, 2015; van der Veen et al., 2005). For example, universities could offer schoolchildren more opportunities for a trial study of their choice, and orientation phases at the beginning of studies could be improved by talking about students' expectations and study conditions.

\section{Limitations and directions for future research}

Although this study's findings provide insights into first-year students' study motivation and career decidedness, we must acknowledge some inherent limitations.

First, the study was restricted to pre-service teachers at one university. Moreover, the sample primarily comprised women, which is representative of teacher programmes. Unfortunately, we could not address gender effects because men were clearly underrepresented in the sample. Previous studies indicate that male pre-service teachers were more likely than female to drop out of teacher training programmes (An et al., 2020; Kim \& Corcoran, 2018). These factors limit the generalisability of the results.

Second, the students involved in the study selected a combination of two out of 17 subjects. Unfortunately, differentiating between fields of study was impossible because most students took a cross-field combination of subjects. Previous research indicates that pre-service and inservice teachers in STEM fields are more likely to leave the profession than their peers in other teaching subjects (Guarino et al., 2006; Klassen \& Chiu, 2011). Further research should take these variables and further socioeconomic variables, at least as control variables, into account to control differences in the learning environment for different subjects.

A third limitation is that this study, like other longitudinal studies, had a high attrition rate (Brahm et al., 2017). No definite answer is available regarding what happened to participants who dropped out. However, more dropouts were male and had lower GPA compared to the 
participants who remained in the study. Further research could identify students with lower GPA and address their development.

Finally, the relatively small sample size meant we did not include the interaction of ability beliefs, interest value and cost as posed in the expectancy-value theory (cf. Nagengast et al., 2011). Further research should examine how these three motivational components interact in the process of dropping out.

Another promising issue for future research is to investigate the interplay between the individual (interest value, perceived task effort) and the environment (study conditions; Schaeper, 2020) to determine which study conditions lead to students' decreased interest and perceived task effort and which strategies help them address these conditions. Our findings indicated that students' interest value and perceived task effort are of particular interest, and their development within the first year should be investigated in more detail.

\section{Conclusion}

The current findings extend the literature on the expectancy-value theory and student dropouts. Specifically, we highlighted the task effort of first-year students as an additional component for long-term career decidedness and the intention to drop out. Moreover, we found that a high interest value at the beginning of the first year was favourable, while high ability beliefs at this time seemed less important in terms of long-term interest value and career decidedness. Therefore, addressing these three motivational components in support services for first-year students should prove favourable for students considering dropping out and should be promising for further research.

Funding Open Access funding enabled and organized by Projekt DEAL. This work was supported by the research project 'TU4Teachers' [reference number 01JA1609], funded by the German Ministry of Education and Research (BMBF; Berlin, Germany) from 2016 until 2019.

\section{Declarations}

Conflict of interest The authors declare no competing interests.

Open Access This article is licensed under a Creative Commons Attribution 4.0 International License, which permits use, sharing, adaptation, distribution and reproduction in any medium or format, as long as you give appropriate credit to the original author(s) and the source, provide a link to the Creative Commons licence, and indicate if changes were made. The images or other third party material in this article are included in the article's Creative Commons licence, unless indicated otherwise in a credit line to the material. If material is not included in the article's Creative Commons licence and your intended use is not permitted by statutory regulation or exceeds the permitted use, you will need to obtain permission directly from the copyright holder. To view a copy of this licence, visit http://creativecommons.org/licenses/by/4.0/.

\section{References}

An, M., Zhang, X., \& Ching, F. N. Y. (2020). Pre-service teachers' career values as determinants of career choice satisfaction: A hierarchical regression analysis. The Asia-Pacific Education Researcher, 92(5), 287. https:// doi.org/10.1007/s40299-020-00529-7. 
Arce, M. E., Crespo, B., \& Míguez-Álvarez, C. (2015). Higher education drop-out in Spain-Particular case of universities in Galicia. International Education Studies, 8. https://doi.org/10.5539/ies.v8n5p247.

Aymans, S. C., \& Kauffeld, S. (2015). To leave or not to leave? Critical factors for university dropout among first-generation students. Zeitschrift Für Hochschulentwicklung, 10, 23-43.

Bandura, A. (1991). Social cognitive theory of self-regulation. Organizational Behavior and Human Decision Processes, 50(2), 248-287.

Barron, K. E., \& Hulleman, C. S. (2015). Expectancy-value-cost model of motivation. In J. D. Wright (Ed.), International encyclopedia of the social and behavioral sciences.

Bennett, R. (2003). Determinants of undergraduate student drop out rates in a university business studies department. Journal of Further and Higher Education, 27(2), 123-141. https://oi.org/10.1080/ 030987703200065154.

Betz, N. E., \& Voyten, K. K. (1997). Efficacy and outcome expectations influence career exploration and decidedness. The Career Development Quarterly, 46(2), 179-189. https://doi.org/10.1002/j.2161-0045. 1997.tb01004.x.

Blüthmann, I., Thiel, F., \& Wolfgramm, C. (2011). Abbruchtendenzen in den Bachelorstudiengängen: Individuelle Schwierigkeiten oder mangelhafte Studienbedingungen. In P. Pasternack (Ed.), (Hrsg.) Die Hochschule: 20. Jahrgang, 1 (2011). Hochschulföderalismus (S. 110-126). Institut für Hochschulforschung $(\mathrm{HoF})$ an der Martin-Luther-Universität Halle-Wittenberg.

Brahm, T., Jenert, T., \& Wagner, D. (2017). The crucial first year: A longitudinal study of students' motivational development at a Swiss Business School. Higher Education, 73(3), 459-478. https://doi.org/10.1007/ s10734-016-0095-8.

Briggs, A. R. J., Clark, J., \& Hall, I. (2012). Building bridges: Understanding student transition to university. Quality in Higher Education, 18(1), 3-21. https://doi.org/10.1080/13538322.2011.614468.

Brinkworth, R., McCann, B., Matthews, C., \& Nordström, K. (2009). First year expectations and experiences: Student and teacher perspectives. Higher Education, 58(2), 157-173. https://doi.org/10.1007/s10734-0089188-3.

Busse, V. (2013). Why do first-year students of German lose motivation during their first year at university? Studies in Higher Education, 38(7), 951-971.

Chesnut, S. R., \& Burley, H. (2015). Self-efficacy as a predictor of commitment to the teaching profession: A meta-analysis. Educational Research Review, 15(2), 1-16. https://doi.org/10.1016/j.edurev.2015.02.001.

Coertjens, L., Brahm, T., Trautwein, C., \& Lindblom-Ylänne, S. (2017). Students' transition into higher education from an international perspective. Higher Education, 73(3), 357-369. https://doi.org/10.1007/ s10734-016-0092-y.

Crisp, G., Palmer, E., \& Turnbull, D. (2009). First year student expectations: Results from a university-wide student survey. Journal of University Teaching \& Learning Practice, 6(1), 11-26.

Deci, E. L., Ryan, R. M., \& Williams, G. C. (1996). Need satisfaction and the self-regulation of learning. Learning and Individual Differences, 8(3), 165-183.

Duchatelet, D., \& Donche, V. (2019). Fostering self-efficacy and self-regulation in higher education: a matter of autonomy support or academic motivation? Higher Education Research \& Development, 38(4), 733-747. https://doi.org/10.1080/07294360.2019.1581143.

Eccles, J. S., \& Wigfield, A. (1995). In the mind of the actor: The structure of adolescents' achievement task values and expectancy-related beliefs. Personality and Social Psychology Bulletin, 21(3), 215-225.

Eccles, J. S., \& Wigfield, A. (2002). Motivational beliefs, values, and goals. Annual Review of Psychology, 53, 109-132. https://doi.org/10.1146/annurev.psych.53.100901.135153.

Eccles, J. S., \& Wigfield, A. (2020). From expectancy-value theory to situated expectancy-value theory: A developmental, social cognitive, and sociocultural perspective on motivation. Contemporary Educational Psychology, 61, 101859. https://doi.org/10.1016/j.cedpsych.2020.101859.

Eccles, J. S., Adler, T. F., Futterman, R., Goff, S. B., Kaczala, C. M., Meece, J. L., \& Midgley, C. (1983). Expectancies, values, and academic behaviors. In J. T. Spence (Ed.), Achievement and achievement motivation (pp. 75-146). Freemann.

Eren, A., \& Rakıcıŏlu-Söylemez, A. (2020). Pre-service teachers' professional commitment, sense of efficacy, and perceptions of unethical teacher behaviours. The Australian Educational Researcher, 22(1), 113. https:// doi.org/10.1007/s13384-020-00396-7.

European Commission. (2015). Dropout and completion in higher education in Europe. Retrieved from http:// supporthere.org/sites/default/files/dropout-completion-he en.pdf.

Flake, J. K., Barron, K. E., Hulleman, C., McCoach, B. D., \& Welsh, M. E. (2015). Measuring cost: The forgotten component of expectancy-value theory. Contemporary Educational Psychology, 41, 232-244. https://doi.org/10.1016/j.cedpsych.2015.03.002.

Gaspard, H., Häfner, I., Parrisius, C., Trautwein, U., \& Nagengast, B. (2017). Assessing task values in five subjects during secondary school: Measurement structure and mean level differences across grade level, 
gender, and academic subject. Contemporary Educational Psychology, 48, 67-84. https://doi.org/10.1016/j. cedpsych.2016.09.003.

Girelli, L., Alivernini, F., Lucidi, F., Cozzolino, M., Savarese, G., Sibilio, M., \& Salvatore, S. (2018). Autonomy supportive contexts, autonomous motivation, and self-efficacy predict academic adjustment of first-year university students. Frontiers in Education, 3. https://doi.org/10.3389/feduc.2018.00095.

Goodman, J. S., \& Blum, T. C. (1996). Assessing the non-random sampling effects of subject attrition in longitudinal research. Journal of Management, 22(4), 627-652. https://doi.org/10.1016/S0149-2063(96) 90027-6.

Gordon, V. N. (1998). Career Decidedness Types: A literature review. The Career Development Quarterly, 46, $386-403$.

Gore, P. A. (2006). Academic self-efficacy as a predictor of college outcomes: Two incremental validity studies. Journal of Career Assessment, 14(1), 92-115. https://doi.org/10.1177/1069072705281367.

Graham, J. W. (2009). Missing data analysis: Making it work in the real world. Annual Review of Psychology, 60, 549-576. https://doi.org/10.1146/annurev.psych.58.110405.085530.

Guarino, C. M., Santibañez, L., \& Daley, G. A. (2006). Teacher recruitment and retention: A review of the recent empirical literature. Review of Educational Research, 76(2), 173-208.

Guo, J., Parker, P. D., Marsh, H. W., \& Morin, A. J. S. (2015). Achievement, motivation, and educational choices: A longitudinal study of expectancy and value using a multiplicative perspective. Developmental Psychology, 51(8), 1163-1176. https://doi.org/10.1037/a0039440.

Heublein, U., Ebert, J., Hutzsch, C., Isleib, S., König, R., Richter, J., \& Woisch, A. (2017). Zwischen Studienerwartungen und Studienwirklichkeit: Ursachen des Studienabbruchs, beruflicher Verbleib der Studienabbrecherinnen und Studienabbrecher und Entwicklung der Studienabbruchquote an deutschen Hochschulen. DZHW.

Hobson, A. J., Giannakaki, M.-S., \& Chambers, G. N. (2009). Who withdraws from initial teacher preparation programmes and why? Educational Research, 51(3), 321-340. https://doi.org/10.1080/ 00131880903156906.

Jacobs, J. E., Lanza, S., Osgood, D. W., Eccles, J. S., \& Wigfield, A. (2002). Changes in children's selfcompetence and values: Gender and domain differences across grades one through twelve. Child Development, 73(2), 509-527.

Jenert, T., Postareff, L., Brahm, T., \& Lindblom-Ylänne, S. (2015). Editorial: Enculturation and development of beginning students. Zeitschrift Für Hochschulentwicklung, 10(4), 9-21.

Jiang, Y., Rosenzweig, E. Q., \& Gaspard, H. (2018). An expectancy-value-cost approach in predicting adolescent students' academic motivation and achievement. Contemporary Educational Psychology, 54, 139-152. https://doi.org/10.1016/j.cedpsych.2018.06.005.

Kim, E., \& Corcoran, R. P. (2018). Factors that influence pre-service teachers' persistence. Teaching and Teacher Education, 70, 204-214. https://doi.org/10.1016/j.tate.2017.11.015.

Klassen, R. M., \& Chiu, M. M. (2011). The occupational commitment and intention to quit of practicing and preservice teachers: Influence of self-efficacy, job stress, and teaching context. Contemporary Educational Psychology, 36(2), 114-129. https://doi.org/10.1016/j.cedpsych.2011.01.002.

Kline, R. B. (2016). Principles and practice of structural equation modeling (4th ed.). Methodology in the social sciences. Guilford publications; The Guilford Press.

Klonek, F. E., Isidor, R., \& Kauffeld, S. (2015). Different stages of entrepreneurship: Lessons from the transtheoretical model of change. Journal of Change Management, 15(1), 43-63. https://doi.org/10.1080/ 14697017.2014.918049.

Klöpping, S., Scherfer, M., Gokus, S., Dachsberger, S., Krieg, A., Wolter, A., \& Umbach, E. (Eds.). (2017). Studienabbruch in den Ingenieurwissenschaften: Empirische Analyse und Best Practices zum Studienerfolg. Herbert Utz Verlag.

Le, H., Robbins, S. B., \& Westrick, P. (2014). Predicting student enrolment and persistence in college STEM fields using an expanded P-E fit framework: A large-scale multilevel study. The Journal of Applied Psychology, 99(5), 915-947. https://doi.org/10.1037/a0035998.

Leese, M. (2010). Bridging the gap: Supporting student transitions into higher education. Journal of Further and Higher Education, 34(2), 239-251. https://doi.org/10.1080/03098771003695494.

Leffers, J. (2007). Studienabbrecher "Staat setzt jährlich 2,2 Milliarden Euro in den Sand". In Der Spiegel Retrieved from http:/www.spiegel.de/lebenundlernen/uni/studienabbrecher-staat-setzt-jaehrlich-2-2milliarden-euro-in-den-sand-a-508930.html.

Lent, R. W., Brown, S. D., \& Hacklett, G. (1994). Toward a unifying social cognitive theory of career and academic interest, choice, and performance. Journal of Vocational Behavior, 45, 79-122.

Li, H., Ngo, H.-Y., \& Cheung, F. (2019). Linking protean career orientation and career decidedness: The mediating role of career decision self-efficacy. Journal of Vocational Behavior, 115, 103322. https://doi.org/ 10.1016/j.jvb.2019.103322. 
Lieberman, D. A., \& Remedios, R. (2007). Do undergraduates' motives for studying change as they progress through their degrees? The British Journal of Educational Psychology, 77(2), 379-395. https://doi.org/10. 1348/000709906X157772.

Marsh, H. W., Lüdtke, O., Muthén, B., Asparouhov, T., Morin, A. J. S., Trautwein, U., \& Nagengast, B. (2010). A new look at the big five factor structure through exploratory structural equation modeling. Psychological Assessment, 22(3), 471-491. https://doi.org/10.1037/a0019227.

Meade, A. W., \& Craig, S. B. (2012). Identifying careless responses in survey data. Psychological Methods, 17(3), 437-455. https://doi.org/10.1037/a0028085.

Mikkonen, J., Ruohoniemi, M., \& Lindblom-Ylänne, S. (2013). The role of individual interest and future goals during the first years of university studies. Studies in Higher Education, 38(1), 71-86. https://doi.org/10. 1080/03075079.2011.564608.

Muthén, L., \& Muthén, B. (1998-2017). Mplus User's Guide: Statistical Analysis With Latent Variables (8th ed.). Muthén \& Muthén.

Nägele, C., \& Neuenschwander, M. P. (2015). Passt der Beruf zu mir? In K. Häfeli, M. P. Neuenschwander, \& S. Schumann (Eds.), Berufliche Passagen im Lebenslauf: Berufsbildungs- und Transitionsforschung in der Schweiz (pp. 49-74). Springer VS. https://doi.org/10.1007/978-3-658-10094-0_3.

Nagengast, B., Marsh, H. W., Scalas, L. F., Xu, M. K., Hau, K.-T., \& Trautwein, U. (2011). Who took the "x" out of expectancy-value theory? A psychological mystery, a substantive-methodological synergy, and a cross-national generalization. Psychological Science, 22(8), 1058-1066. https://doi.org/10.1177/ 0956797611415540 .

Noyens, D., Donche, V., Coertjens, L., van Daal, T., \& van Petegem, P. (2019). The directional links between student's academic motivation and social integration during the first year of higher education. European Journal of Psychology of Education, 34(1), 67-86.

OECD. (2019). Education at a Glance 2019: OECD Indicators. Bielefeld. https://doi.org/10.3278/6001821mw.

Perez, T., Cromley, J. G., \& Kaplan, A. (2014). The role of identity development, values, and costs in college STEM retention. Journal of Educational Psychology, 106(1), 315-329. https://doi.org/10.1037/a0034027.

Perryman, J., \& Calvert, G. (2019). What motivates people to teach, and why do they leave?: Accountability, performativity and teacher retention. British Journal of Educational Studies, 1-21 http://arxiv.org/pdf/1005. 2019v1.

Pohlmann, B., \& Möller, J. (2010). Fragebogen zur Erfassung der Motivation für die Wahl des Lehramtsstudiums (FEMOLA). Zeitschrift Für Pädagogische Psychologie, 24(1), 73-84. https://doi.org/ 10.1024/1010-0652/a000005.

Restubog, S. L. D., Florentino, A. R., \& Garcia, P. R. J. M. (2010). The mediating roles of career self-efficacy and career decidedness in the relationship between contextual support and persistence. Journal of Vocational Behavior, 77(2), 186-195. https://doi.org/10.1016/j.jvb.2010.06.005.

Richardson, M., Abraham, C., \& Bond, R. (2012). Psychological correlated of university students' academic performance: A systematic review and meta-analysis. Psychological Bulletin, 138(2).

Robbins, S. B., Allen, J., Casillas, A., Peterson, C. H., \& Le, H. (2006). Unraveling the differential effects of motivational and skills, social, and self-management measures from traditional predictors of college outcomes. Journal of Educational Psychology, 98(3), 598-616. https://doi.org/10.1037/0022-0663.98.3.598.

Roberts, D. (2012). Modelling withdrawal and persistence for initial teacher training: Revising Tinto's longitudinal model of departure. British Educational Research Journal, 38(6), 953-975. https://doi.org/10.1080/ 01411926.2011 .603035 .

Sarcletti, A., \& Müller, S. (2011). Zum Stand der Studienabbruchforschung. Theoretische Perspektiven, zentrale Ergebnisse und methodische Anforderungen an künftige Studien. Zeitschrift Für Bildungsforschung, 1(3), 235-248. https://doi.org/10.1007/s35834-011-0020-2.

Schaeper, H. (2020). The first year in higher education: The role of individual factors and the learning environment for academic integration. Higher Education, 79(1), 95-110. https://doi.org/10.1007/s10734019-00398-0.

Scherfer, M., \& Weber, H. (2014). Studienabbruch und Studienwechsel an der Universität Stuttgart. Stuttgart.

Scherrer, V., \& Preckel, F. (2019). Development of motivational variables and self-esteem during the school career: A meta-analysis of longitudinal studies. Review of Educational Research, 89(2), 211-258. https://doi. org/10.3102/0034654318819127.

Schnettler, T., Bobe, J., Scheunemann, A., Fries, S., \& Grunschel, C. (2020). Is it still worth it? Applying expectancyvalue theory to investigate the intraindividual motivational process of forming intentions to drop out from university. Motivation and Emotion, 44(4), 491-507. https://oi.org/10.1007/s11031-020-09822-w.

Tabachnick, B. G., \& Fidell, L. S. (2006). Using multivariate statistics (5th ed.). Pearson.

Tett, L., Cree, V. E., \& Christie, H. (2017). From further to higher education: Transition as an on-going process. Higher Education, 73(3), 389-406. https://doi.org/10.1007/s10734-016-0101-1. 
Trautwein, C., \& Bosse, E. (2017). The first year in higher education-Critical requirements from the student perspective. Higher Education, 73(3), 371-387. https://doi.org/10.1007/s10734-016-0098-5.

Trautwein, C., \& Stolz, K. (2015). "Press on regardless!" - The role of volitional control in the first year of higher education. Zeitschrift Für Hochschulentwicklung, 10(4), 123-143.

Van der Meer, J., Scott, S., \& Pratt, K. (2018). First semester academic performance: The importance of early indicators of non-engagement. Student Success, 9(4), 1-12. https://doi.org/10.5204/ssj.v9i4.652.

Van der Veen, I., Jong, U. d., van Leeuwen, M., \& Korteweg, J. A. (2005). The development of higher education students' interest in their subject: The case of higher professional education in the Netherlands. Studies in Higher Education, 30(3), 275-289. https://doi.org/10.1080/03075070500095705.

Wang, J., \& Wang, X. (2012). Structural equation modeling: Applications using Mplus. Wiley series in probability and statistics. John Wiley \& Sons.

Watt, H. M. G. (2004). Development of adolescents' self-perceptions, values, and task perceptions according to gender and domain in 7th- through 11th-grade Australian students. Child Development, 75(5), 1556-1574. https://doi.org/10.1111/j.1467-8624.2004.00757.x.

Watt, H. M. G., Bucich, M., \& Dacosta, L. (2019). Adolescents' motivational profiles in mathematics and science: Associations with achievement striving, career aspirations and psychological wellbeing. Frontiers in Psychology, 10, 990. https://doi.org/10.3389/fpsyg.2019.00990.

Wigfield, A., \& Cambria, J. (2010). Expectancy-value theory: Retrospective and prospective. Advances in Motivation and Achievement, 16A, 35-70.

Wigfield, A., \& Eccles, J. S. (2000). Expectancy-value theory of achievement motivation. Contemporary Educational Psychology, 25(1), 68-81. https://doi.org/10.1006/ceps.1999.1015.

Wigfield, A., Eccles, J. S., Iver, D. M., Reuman, D. A., \& Midgley, C. (1991). Transitions during early adolescence: Changes in children's domain-specific self-perceptions and general self-esteem across the transition to junior high school. Developmental Psychology, 27(4), 552-565.

Wright, S. L., Jenkins-Guarnieri, M. A., \& Murdock, J. L. (2013). Career development among first-year college students. Journal of Career Development, 40(4), 292-310. https://doi.org/10.1177/0894845312455509.

Yentes, R., \& Wilhelm, F. (2018). Procedures for computing indices of careless responding: Package "careless" (No. 1). https://doi.org/10.1016/j.jrp.2004.09.009.

Publisher's note Springer Nature remains neutral with regard to jurisdictional claims in published maps and institutional affiliations. 